tolerated, carries the potential risks related to the use of plasma derivative products. The proposed indications for high dose gammaglobulin infusion are (a) when a rapid increase in platelet count is required, (b) as a substitute for immunosuppressive drugs, (c) when steroid treatment is ineffective, and (d) as an attempt to avoid splenectomy. ${ }^{6}$

It is worth considering treatment with pulses of methylprednisolone in children who are unresponsive to standard corticosteroid and high dose intravenous gammaglobulin treatments before considering other therapeutic procedures.

This study was supported by the CNR (grant $83.02571 \cdot 04$ ) and the Ministero Pubblica Sotrusione.

\section{References}

${ }^{1}$ Stuart MJ, McKenna R. Diseases of coagulation: the platelet and vasculature. In: Nathan and Osky, eds. Hematology of infancy and childhood vol II, 2nd ed. Philadelphia, London, Toronto: WB Saunders, 1981:1234-338.

2 Marder VJ, Nusbacher J, Anderson FW. One year follow up of plasma exchange therapy in 14 patients with thrombocytopenic purpura. Transfusion 1981;21:291-8.

3 Inbach P, Barandun S, D'Apuzzo V, et al. High-dose intravenous gammaglobulin for idiopathic thrombocytopenic purpura in childhood. Lancet $1981 ; \mathbf{i}: 1228-31$.

4 Oto A, Sozen T, Ozisik Y. Pulse methylprednisolone therapy in idiopathic thrombocytopenic purpura. Acta Haematol 1983;70:345.

5 Eraklis AJ, Filler RM. Splenectomy in childhood: a review of 1413 cases. $J$ Pediatr Surg 1972;7:382-8.

${ }^{6}$ Mori PG, Mancuso G, Del Principe D, et al. Chronic idiopathic thrombocytopenia treated with immunoglobulin. Arch Dis Child 1983;58:851-5.

Correspondence to Dr A Menichelli, Department of Pediatrics, University of Rome, "La Sapienza", Viale Regina Elena 324, 00161 Rome, Italy.

Received 29 March 1984

\title{
High volume milk feeds for preterm infants
}

\author{
M A LEWIS AND B A M SMITH
}

Nether Edge Hospital, Sheffield

SUMMARY Fifty nine preterm infants of between 1.0 and $2.0 \mathrm{~kg}$ birthweight who were fed $250 \mathrm{ml} / \mathrm{kg} /$ day of breast milk or standard formulas gained weight at the intrauterine rate without complications. It is suggested that high volume feeding is a satisfactory alternative to low birthweight formula milks and is more desirable in infants who are to be breast fed.

Current practice includes the restriction of feed volumes given to preterm infants to between 150 and $200 \mathrm{ml} / \mathrm{kg} /$ day. This has accentuated the difficulty in achieving satisfactory postnatal growth and has led to the development of special low birthweight formulas. ${ }^{1}$ Doubt about the necessity for volume restriction led us to review retrospectively the available data on growth of preterm infants in our unit when feed volumes were not restricted and when only breast milk or a standard formula was used.

\section{Patients and methods}

We reviewed the hospital records of all infants with a birthweight of less than $2.0 \mathrm{~kg}$ born at Nether Edge Hospital, Sheffield during 1976 to 1978 inclusive.
Seven infants weighed less than $1.0 \mathrm{~kg}$ and all died. There were 87 infants with birthweights between 1.0 and $2.0 \mathrm{~kg}: 18$ of these were born at term and are not included in this study. Ten of the remainder died within the first postnatal week (six from respiratory distress syndrome, three from lethal congenital anomalies, and one from severe birth asphyxia). This left 59 preterm infants. Thirty were appropriate for gestational age and 29 were small for gestational age (weight less than the 10th centile). Seventeen infants weighed less than $1.5 \mathrm{~kg}$ (five appropriate and six small for gestational age). Thirteen of the 59 infants had respiratory problems requiring increased inspired oxygen concentrations for more than 48 hours after birth. Several were also given continuous positive airways pressure. Facilities for mechanical ventilation were not available. Several infants received antibiotics for presumed or proved infection and several received theophylline for apnoea.

Infants were breast, bottle, tube, or spoon fed; no transpyloric feeding or parenteral nutrition was used. Volumes of feeds were steadily increased, according to tolerance, until satisfactory weight gain was achieved. When ready to breast feed infants were 'test weighed' and if necessary were complemented with expressed breast milk until two to three days before discharge. Feed charts had been 
retained so the volume of milk given to each infant daily could be calculated. Infants were weighed every three days unless there were indications to weigh more frequently. Detailed anthropometric data were not available.

Infants who were to be breast fed were given only their own mothers' milk or banked breast milk. The cows' milk formula used was Wyeth S M A Gold Cap. For well infants weight gain was studied from day six until discharge. For ill infants weight gain was studied from day nine until discharge. Eight of the 30 infants appropriate for gestational age and four of the 29 infants who were small for gestational age were classed as 'ill infants'. Seven of these weighed less than $1.5 \mathrm{~kg}$. All 59 infants survived.

\section{Results}

Data on feeding, weight gain, gestational age, and length of hospital stay, is shown in the Table. In both groups of infants a mean rate of weight gain similar to that expected in utero was achieved (15.8 $\mathrm{gm} / \mathrm{kg} /$ day for appropriate for gestational age infants and $17.0 \mathrm{gm} / \mathrm{kg} /$ day for infants who were small for gestational age). A mean intake of a little over 250 $\mathrm{ml} / \mathrm{kg} /$ day was required to achieve this rate of weight gain. The results for infants with a birthweight of less than $1.5 \mathrm{~kg}$ were as good as those for the group as a whole $(16.8 \mathrm{gm} / \mathrm{kg} /$ day, mean intake 262 $\mathrm{ml} / \mathrm{kg} /$ day). Similarly, the rate of weight gain and maximum feed volumes of the breast milk fed infants (27) did not differ significantly (Student's $t$ test) from that of the formula fed infants (15.9 $\mathrm{gm} / \mathrm{kg} /$ day, mean intake $257 \mathrm{ml} / \mathrm{kg} /$ day).

No infant failed to tolerate the volume of milk required to give consistent weight gain and there were no complications. In particular, there were no cases of persistent vomiting, diarrhoea, necrotizing enterocolitis, or aspiration pneumonia. No infants were noted to be oedematous nor did any become hyponatraemic. No infants required either surgical or pharmocological closure of a persistent ductus arteriosus.

\section{Discussion}

In this retrospective survey we could find no evidence of complications secondary to the use of high volume feeds. All the infants thrived, though those who were small for gestational age did not all show catch up growth. Valman $e t a l,{ }^{2}$ using volumes of $300 \mathrm{ml} / \mathrm{kg} /$ day by continuous nasogastric drip, had few complications. All their patients thrived and, using these larger volumes, the small for gestational age infants showed catch up growth. Davies, ${ }^{3}$ using smaller volumes, found that immature preterm infants did not thrive on expressed breast milk. He put this down to the low protein content of breast milk- $250 \mathrm{ml} / \mathrm{kg} /$ day gave $2.75 \mathrm{gm} / \mathrm{kg} /$ day of protein. The protein content of low birthweight formulas varies from 2.7 to $3.6 \mathrm{gm} / 150 \mathrm{ml}$. The amino acid composition of breast milk protein is advantageous,${ }^{4}$ enabling infants to thrive on lesser protein intakes than are required from cows' milk preparations.

High volume feeds provide approximately 160 $\mathrm{Kcal} / \mathrm{kg} /$ day, $40 \mathrm{Kcal} / \mathrm{kg} /$ day more than provided by normal volumes of low birthweight formulas. This extra energy is mainly in the form of fat $(9.0 \mathrm{gm} / 250$ $\mathrm{ml}$ for SMA Gold Cap and $6.6 \mathrm{gm} / 150 \mathrm{ml}$ for SMA low birthweight formula). This caused no problems. Hanmer et al ${ }^{5}$ have shown that giving infants 10 $\mathrm{gm} / \mathrm{kg} / \mathrm{day}$ of fat leads to increased absorption without steatorrhoea or metabolic disturbance. The large lactose load caused no diarrhoea.

Low birthweight formulas are of value in the neonatal intensive care unit. We would suggest, however, that high volume feeding is a satisfactory alternative in the many special care nurseries dealing with well infants above 30 weeks' gestation and $1.0 \mathrm{~kg}$ birthweight. Long term advantages from the special formulation of milks for low birthweight infants have yet to be proved. Given the greater

Table Clinical data and growth in appropriate for gestational age (AFGA) and small for gestational age (SFGA) preterm infants

\begin{tabular}{|c|c|c|c|}
\hline & $\begin{array}{l}\text { AFGA } \\
(n=30) \\
\text { Mean (SD) }\end{array}$ & $\begin{array}{l}S F G A \\
(n=29) \\
\text { Mean (SD) }\end{array}$ & $\begin{array}{l}\text { Birthweight }<1.5 \mathrm{~kg} \\
(n=17) \\
\text { Mean (SD) }\end{array}$ \\
\hline Birthweight (kg) & $1 \cdot 71(0 \cdot 22)$ & $1 \cdot 60(0.28)$ & $1 \cdot 31(0 \cdot 13)$ \\
\hline Gestation at birth (weeks) & $31 \cdot 7(1 \cdot 3)$ & $33.8(1.4)$ & $31.9(1.8)$ \\
\hline Discharge weight $(\mathrm{kg})$ & $2.68(0.19)$ & $2.67(0.28)$ & $2.69(0.32)$ \\
\hline Weight gain (gm/day) & $33.8(3.8)$ & $35 \cdot 8(6.5)$ & $33 \cdot 2(6 \cdot 6)$ \\
\hline Weight gain (gm/kg/day) & $15 \cdot 8(1.6)$ & $17 \cdot 0(3 \cdot 0)$ & $16 \cdot 8(3 \cdot 2)$ \\
\hline Maximum intake $(\mathrm{ml} / \mathrm{kg} /$ day $)$ & $251 \cdot 2(20 \cdot 7)$ & $258 \cdot 3(23 \cdot 2)$ & $261.9(28.2)$ \\
\hline Age at discharge (days) & $39(7 \cdot 9)$ & $39(19 \cdot 5)$ & $51.9(19.9)$ \\
\hline Fully breast fed on discharge (\%) & $46 \cdot 7$ & $34 \cdot 5$ & $35 \cdot 3$ \\
\hline
\end{tabular}


incidence of breast feeding in all social classes today, however, it would surely be wrong to abandon the use of breast milk, with all its advantages, ${ }^{46}$ for a cows' milk formula for low birthweight infants on the mistaken premise that adequate growth cannot be achieved with the former.

We thank the sisters and nurses on special care baby unit for the accurate record keeping which made this study possible.

\section{References}

${ }^{1}$ French TJ, Colbeck M, Burman D, Spiedel BD, Hendey RA. A modified cows' milk formula suitable for low birthweight infants. Arch Dis Child 1982;57:507-10.

2 Valman HB, Heath CD, Brown RJK. Continuous intragastric milk feeds in infants of low birthweights. Br Med J 1972;iii: $547-50$.
${ }^{3}$ Davies DP. Adequacy of expressed breast milk for early growth of preterm infants. Arch Dis Child 1977;52:296-301.

${ }^{4}$ American Academy of Pediatrics: Committee on Nutrition. Nutritional needs of low birthweight infants. Pediatrics 1977;60:519-30.

5 Hanmer OJ, Houlsby WT, Thom H, Ross IS, Lloyd DJ, Russell G. Fat as an energy supplement for preterm infants. Arch Dis Child 1982;57:503-6.

${ }^{6}$ Narayanan I, Prakesh K, Guzral VV. The value of human milk in the prevention of infection in the low birthweight infant. $J$ Pediatr 1981;99:496-8.

Correspondence to $\mathrm{Dr}$ B A M Smith, Nether Edge Hospital, Osborne Road, Sheffield S11 9EL.

Received 7 March 1984

An article by Lucas et al on preterm formula feeds appears on pp 722-30 of this issue.

\title{
Hypergonadotropic hypogonadism in two sisters with galactosaemia
}

\author{
H P SCHWARZ, H MOSER, J SCHILD, AND K ZUPPINGER \\ Department of Paediatrics, Inselspital, Bern, Switzerland
}

SUMMARY Two sisters with transferase deficiency galactosaemia presented with hypergonadotropic hypogonadism. In the younger girl galactosaemia was documented first at 9 months of age, although she had never been exposed to exogenous galactose in utero or after birth.

Galactosaemia due to deficiency of galactose-1phosphate uridyl transferase (transferase deficiency galactosaemia) is characterised by a well known toxicity syndrome. Dietary restriction of galactose may prevent or reverse most of the symptoms. Only recently has ovarian failure been recognised as a complication of this metabolic disorder ${ }^{12}$ and we are following two sisters who presented with hypergonadotropic hypogonadism at a very young age.

\section{Case reports}

Patient 1. The older of the two girls was born at term by caesarean section to a 23 year old gravida I, para 0 . Her birthweight was $3220 \mathrm{~g}$. She was breast fed but started to vomit and when admitted to hospital at age 9 days was moderately dehydrated and jaundiced. Total bilirubin was $262 \mu \mathrm{mol} / \mathrm{l}$, plasma glucose $3 \cdot 1 \mathrm{mmol} / \mathrm{l}$, serum glutamic oxaloacetic transaminase $123 \mathrm{IU} / \mathrm{l}$, serum glutamic pyruvic transaminase $136 \mathrm{IU} / \mathrm{l}$, alkaline phosphatase 527
IU/l (normal 22 to 98 ), prothrombin time 5\%, plasma galactose $1.4 \mathrm{mmol} / \mathrm{l}(25.4 \mathrm{mg} / \mathrm{dl})$, and erythrocyte galactose-1-phosphate $4.8 \mathrm{mmol} / \mathrm{l}(125$ $\mathrm{mg} / \mathrm{dl}$ ). Generalised aminoaciduria was present. She was given intravenous glucose and one day later was started on a lactose free soy based formula. Galactosaemia was confirmed by a practically absent transferase activity of $0.007 \mu \mathrm{mol} / \mathrm{min} / \mathrm{g}$ haemoglobin ( $1.4 \%$ of normal). After 8 days of treatment her erythrocyte galactose-1-phosphate concentration had dropped to $1.9 \mathrm{mmol} / 1$ but this was still greatly raised five weeks later $(542 \mu \mathrm{mol} / \mathrm{l})$. Subsequent galactose-1-phosphate concentrations, determined three monthly, were between 0 and $235 \mu \mathrm{mol} / \mathrm{l}$. At 2 years of age her IQ (Brunet-Lézine) was 94. Liver enzymes were normal but her basal follicle stimulating hormone concentration was raised (Table); sex chromatin was normal. At $3 \frac{1 / 2}{2}$ years of age a luteinising hormone releasing hormone test $(100 \mu \mathrm{g}$ iv) showed particularly high basal and peak follicle stimulating hormone concentrations as well as a raised peak luteinising hormone concentration. She is now 4 years old and her height, weight, and head circumference are within normal limits. There are no cataracts on slit lamp examination but psychological testing has shown an IQ (Kramer) of 75 with substantial deficits in expressive speech and articulation.

Heterozygosity for galactosaemia was proved in both parents by quantitative measurement of trans- 